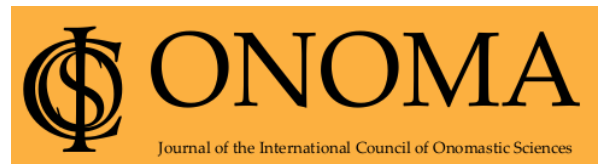

Onoma 56

Journal of the International Council of Onomastic Sciences

ISSN: 0078-463X; e-ISSN: 1783-1644

Journal homepage: https://onomajournal.org/

\title{
Impact of bilingualism and the difficulties of having minority-specific names in another dominant society: Turkish context for minority Kurdish society
}

\section{Süleyman Kasap*}

Education Faculty, ELT Department

Van Yuzuncu Yil University, Turkey

To cite this article: Kasap, Süleyman. 2021. Impact of bilingualism and the difficulties of having minority-specific names in another dominant society: Turkish context for minority Kurdish society. Onoma 56, 167-186. DOI: 10.34158/ONOMA.56/2021/9

To link to this article: https://doi.org/10.34158/ONOMA.56/2021/9

(C) Onoma and the author.

\section{Article history}

Received on 17 October 2021.

Final form accepted on 6 December 2021.

Published online on 13 December 2021.

Impact of bilingualism and the difficulties of having minority-specific names in another dominant society: Turkish context for minority Kurdish society

Abstract: This article is concerned with the issue of bilingualism and minority societies. Obviously, due to the vastness of the topic, not all the cases worldwide can be covered. Hence the study focused on the Turkish context. Namely, the study examined the Kurdish minority group in dominant Turkish society and the related aspects. In so doing, the paper is divided into two parts. The first part deals with what bilingualism is. As discussed in the paper, some people benefit from the use of more 
than one language when they communicate with the people with different ethnic or cultural backgrounds, yet the paper argues that the use of bilingualism also faces difficulties and assimilation in the countries where the hegemonic ideologies and cultures prohibit the use of more than one native language with fear of losing unity and native language. Secondly, the paper examines the difficulties Kurdish people face when they want to have Kurdish-specific names in a predominantly Turkish society. Hence the paper analyses the controversy over Kurdish naming in Turkey through a qualitative research design, in which semi-structured interviews with seven participants were used. The results show that the participants had to go through many hardships with their names written in Kurdish letters. Therefore, they have negatively been influenced nearly in almost all aspects of their lives because of having names that have got odd meanings or became meaningless at all in Turkish.

Keywords: Bilingualism, minority society, Kurdish language, naming, Kurdish ethnicity.

\section{Impact du bilinguisme et difficultés d'avoir des noms propres à une minorité dans une autre société dominante : contexte turc pour la société kurde minoritaire}

Résumé : Cet article porte sur la question du bilinguisme et des sociétés minoritaires. De toute évidence, en raison de l'immensité du sujet, tous les cas dans le monde ne peuvent pas être couverts. L'étude s'est donc concentrée sur le contexte turc. À savoir, l'étude a examiné le groupe minoritaire kurde dans la société turque dominante et les aspects connexes. Ce faisant, le document est divisé en deux parties. La première partie traite de ce qu'est le bilinguisme. Comme indiqué dans l'article, certaines personnes bénéficient de l'utilisation de plusieurs langues lorsqu'elles communiquent avec des personnes d'origines ethniques ou culturelles différentes, mais l'article soutient que l'utilisation du bilinguisme se heurte également à des difficultés et à l'assimilation dans les pays où l'hégémonie hégémonique les idéologies et les cultures interdisent l'utilisation de plus d'une langue maternelle de peur de perdre l'unité et la langue maternelle. Deuxièmement, l'article examine les difficultés auxquelles les Kurdes sont confrontés lorsqu'ils veulent avoir des noms spécifiques au kurde dans une société à prédominance turque. Par conséquent, l'article analyse la controverse sur la dénomination kurde en Turquie à travers une conception de recherche qualitative, dans laquelle des entretiens semi-structurés avec sept participants ont été utilisés. Les résultats montrent que les participants ont dû traverser de nombreuses épreuves avec leurs noms écrits en lettres kurdes. Par conséquent, ils ont été négativement influencés dans presque tous les aspects de leur vie à cause d'avoir des noms qui ont des significations étranges ou qui sont devenus sans signification du tout en turc.

kurde.

Mots-clés : Bilinguisme, société minoritaire, langue kurde, nommage, ethnicité

\section{Auswirkungen der Zweisprachigkeit und die Schwierigkeiten, minderheitenspezifische Namen in einer anderen dominanten Gesellschaft zu haben: Türkischer Kontext für die kurdische Minderheitengesellschaft}

Zusammenfassung: Dieser Artikel beschäftigt sich mit dem Thema Zweisprachigkeit und Minderheitengesellschaften. Aufgrund der Breite des Themas kann natürlich Nicht alle Fälle weltweit abgedeckt werden. Daher konzentrierte sich 
die Studie auf den türkischen Kontext. Die Studie untersuchte nämlich die kurdische Minderheitengruppe in der dominierenden türkischen Gesellschaft und die damit verbundenen Aspekte. Dabei gliedert sich das Papier in zwei Teile. Der erste Teil beschäftigt sich damit, was Zweisprachigkeit ist. Wie in dem Papier suchen, profitieren manche Menschen von der Verwendung von mehr als einer Sprache, wenn sie mit Menschen mit unterschiedlichen Ethnien oder kulturellem Hintergrund kommunizieren, dass aber das Papier argumentiert, dass die Verwendung der Zweikeit auch in den Ländern, in denen die Hegemonie-Ideologien verwendet werden und Kulturen verbieten den Gebrauch von mehr als einer Muttersprache aus Angst, Einheit und Muttersprache zu verlieren. Zweite untersucht das Papier sterben Schwierigkeiten, mit denen kurdische Menschen konfrontiert sind, wenn sie in einer überwiegend türkischen Gesellschaft kurdisch-spezifische Namen haben möchten. Daher analysiert der Beitrag die Kontroverse um die kurdische Namensgebung in der Türkei anhand eines qualitativen Forschungsdesigns, bei dem halbstrukturierte Interviews mit sieben Teilnehmern verwendet wurden. Die Ergebnisse zeigen, dass die Teilnehmer mit ihren in kurdischen Buchstaben geschriebenen Namen viele Strapazen durchmachen. Daher wurden sie in fast allen Aspekten ihres Lebens negativ beeinflusst, weil sie Namen haben, sterben seltsame Bedeutungen Haben oder im Türkischen überhaupt bedeutungslos wurden.

Schlüsselbegriffe: Zweisprachigkeit, Minderheitengesellschaft, kurdische Sprache, Namensgebung, kurdische Ethnizität. 


\title{
Impact of bilingualism and the difficulties of having minority-specific names in another dominant society: Turkish context for minority Kurdish society
}

\author{
SÜLEYMAN KASAP
}

\section{Introduction}

Bilingualism is a notion used to describe a phenomenon of using two or more languages for communication. The synonym for bilingualism is multilingualism, while monolingualism is an antonym to utilise only one language. Research shows that there are about six thousand eight hundred languages globally, and only two hundred of them are nation-state (Romaine 2006). These numbers give us a chance to estimate that bilingualism is practically seen in every country globally, no matter if the language is recognised officially or not (Romaine 1995: 369). It will also be relevant to mention that some countries in Africa, such as Nigeria, and Ghana recognise only one official language, despite most of the population utilising one or even more languages in their everyday lives (Poissant 2005). This situation creates consequent problems for democracy, and each state deals with them in its way. For example, some countries adopt programmes regarding language and cultural diversity, various educational programmes in order to foster bilingual education in their states. On the other hand, some countries are afraid of language and culture diversity programmes to lead to social division and ethnocentrism. Hence, they introduce the policies of assimilation or integration (Poissant 2005). An article by Wei (2006) in Encyclopaedia of language and linguistics suggests that bilingualism occurs due to substantial language contact among people who speak different languages. Some people do it by their own choice, while others are forced to do so due to existing circumstances. Moreover, agents like education, religion and culture, technology and natural disasters are among the factors that contribute to language intercourse (Wei 2006). In this study, we focus on Turkey as a country and Kurdish society, particularly the biggest minority group of the country. In this regard, it is necessary to state that Turkey's minority regime is an outcome of the process that was shaped under the legal framework of the Treaty of Lausanne dated back to 1923 and the political plans and approaches of the Turkish state and society in respect to minorities (Toktas \& Aras 2009). Turkey is a diverse country, which encompasses various ethnicities other than 
Turks, such as Armenians, Assyrians, Alevi, Arabs, Circassians, Greeks, Kurds, Laz and Zaza (Ozfidan \& Burlbaw \& Aydin 2018). Kurdish, Laz and Arabic languages were once started to be taught at schools as elective courses, however the scarcity of educational resources in these languages negatively impacted the issue (Kaya 2015). Kurds speak a language that belongs to the Indo-Iranian branch of the Indo-European language family and is called Kurdish. The Kurdish language is related to Persian and has no resemblance to Turkish and Arabic. It has four different dialects spoken all over a vast territory. As an ethnicity, Kurds faced many challenges throughout the Turkish history. The situation was even enhanced by several laws passed, as the "Law on the Acceptance and Application of Latin Letters" dated back to 1928, and Surname Law from 1934 which affected Kurds as an ethnicity. During these years the Kurds chose Turkish names for themselves and their names, so their chances to survive as a pure ethnicity were diminished.

Moreover, there is a controversy over Kurdish naming, which creates problems for people coming from this background. It influences nearly all the aspects of their lives. This study aims to examine the difficulties caused due to having minority specific names, and aims to look deeper at the reasons. Obviously, we aim to do so by taking into consideration the stories of human who faced the hardships in this regard or whose life was at least once affected by the controversy over naming.

\section{Bilingualism and minority societies}

Edwards (2005) states that everyone is bilingual, as all people can learn one or more languages besides their mother tongue. Bilinguals are differentiated into two groups: one of them majority bilinguals - people who speak their mother tongue as "the national language" and a foreign language; and minority bilinguals speaking their minority language and the state language, in other words standard language of the country they are living in (Feng 2005, as cited in Nguyen 2018). Research shows that there are more minority bilinguals than majority bilinguals, despite the fact that the former group has a limited access to "linguistic capital" (Bourdieu 1991, as cited in Nguyen 2018). Linguistic capital is often related with the more powerful language, which is spoken by the majority, so turns out that the majority bilinguals have a better access to social benefits and mobility chances.

The definition of "minority language" can be confusing. So, there is a definition often quoted in the literature (see the bibliography cited in Gorter 2013), which is given by the Council of Europe in the European Charter for Regional or Minority Languages (1992). According to the definition given in the Charter, minority languages are "the languages that are traditionally used within a given territory of a state by nationals of that state who form a group 
numerically smaller than the rest of the state's population and [are] different from the official language(s) of that state" (Gorter 2013:2). This definition gives us a right to assume that the great power here belongs to the state, so it is a state that defines if to give an official recognition to a minority language on its territory or not (Gorter 2013). Moreover, the definition excludes all kinds of dialects of the official language of the state and the languages of migrants. Additionally, Gorter (2013) believes that minority language speakers are multilingual by nature or by necessity. However, they all were monolingual in the beginning, but with the emergence and development of the state had no other way than also picking up the state language and consequently becoming multilingual (Gorter 2013). Cases of the Basque Country, Friesland and Wales in Europe can be examples here.

Moving on with the Vietnamese case, there is a need to mention that there are approximately one hundred languages and language varieties spoken across all the minority communities in the country, and some of these languages do not have a proper writing system till now. The official language is Vietnamese, also called the language of Kinh people, and it brings under one umbrella the languages of fifty-four minority groups (Nguyen 2018). People use their minority language for interaction in their families and communities; however, they need an official language for communication in broader society.

The government of Vietnam initiated some policies and programmes to support minority people, their languages and maintain their ethnic cultures. According to the Constitution (2013), all citizens' right and responsibility, despite their ethnic affiliation, to learn the Vietnamese language, which is crucial for ethnic coherence, development, and equity (Lavoie 2011). However, Nguyen $\&$ Hamid $(2016,2017)$ argue that the necessary value and attention are not given to ethnic languages; hence, the domination of one particular language, Vietnamese in this case, leads to cultural and language loss of many minority communities. Research suggests that language and identity are indivisible two notions (Tabouret-Keller 1998), and the identity can be shown in an individual's language practices, language beliefs and language management (Nguyen 2018). They are also the components of bilingual identity, according to Spolsky (2004). Additionally, Fielding (2015) identifies four substantial agents of bilingual identity, which are as follows: ethnic-cultural factors, social factors, interaction and investment. The most influential groups affecting an individual's identity are ethnic-cultural and social factors (Norton 2006, as cited in Nguyen 2018). However, for ethnic minority groups, ethnic-cultural factors mainly consist of shared facts, beliefs and values of group experience, which make them feel as a part of their ethnic group (Myers-Scotton 2007). Furthermore, these factors can determine individuals" "attitudes and preference for one language over the others" (Nguyen 2018: 4). Family, context, institutions and peers are considered under social factors, and are also essential for individuals' perception of identity and language (see Nguyen 2018).

In Bolivia, for instance, thirty-six ethnic languages are spoken, besides 
the official Spanish language. The Constitution (2009) signifies the country as a multilingual state and requires officials and public employees to be fluent in at least two of the country's languages (Drange 2011). However, in many cases people from ethnic groups feel unaccepted in the society due to the fact that they possess the elements of a different culture and speak a different language, thus they have to master the dominant language in order to get accepted by the society (Drange 2011). Plenty of negative outcomes of this practice occurred, such as individuals of minority societies started to deny their ethnicity, feel guilty for their origins and parents did not want their children to speak their native languages (Skutnabb-Kangas 1981: 16). When moving to urban areas people from ethnic groups feel a need to change their surnames to Spanish ones in order to avoid discrimination; moreover, Spanish is important for economic and social reasons (Drange 2011).

\section{Kurdish language and ethnicity}

Kurds are one of the biggest ethnic groups that do not have a nation-state (see Karimova \& Deverell 2001). If to look at the minorities' map, we see that they make up a significant percentage of minority population in the countries where they live in the Middle East, particularly, Turkey, Iran, Iraq, Syria and Azerbaijan; furthermore, they represent a considerable percentage of population in some European countries, such as Germany, the Netherlands, Sweden (Çelik 2012). It is estimated that Kurds in Turkey constitute 15-20\% of overall population (Andrews 1992; Gunter 1997; McDowall 1997).

There are two reasons which make it difficult to describe Kurds as a homogeneous group. The first reason is due to geographical diversity and distribution. What it means is that four main dialects, Kurmanci, Sorani, Zazaki, and Gorani are spoken in the Kurdish language and they are spread to territories of different countries. For instance, Kurmanci and Zazaki are spoken by Kurds in Turkey and Syria; Sorani and Gorani are spoken by Kurds in Iran and Iraq. The rest of the Kurds found in former Soviet Republics (Armenia, Azerbaijan, Kyrgyzstan, Kazakhstan) and Lebanon speak Kurmanci dialect (Izady 1992).

The other reason is due to the various languages spoken and religions followed, such as Sunni, Alevi and Yezidi (Çelik 2012). Kurds in Turkey differentiate themselves from other groups by their very specific culture and language (Çelik 2012). However, differing themselves on the basis of language can also be troublesome. There are individuals of Kurdish ethnicity that have never learned to speak Kurdish due to several reasons. One reason is that they were not encouraged by their parents to master the language because parents, in their turn, were afraid to teach them; and the other reason is because the individuals of Kurdish ethnicity were assimilated to the culture of countries where they live, in this case it is Turkish culture (Çelik 2012). The Ottoman 
Empire united many different ethnicities with various languages and cultures, and representatives of these ethnicities had close relations with each other. However, none of the ethnic groups had a self-consciousness of an ethnicity, thus they mostly associated themselves on religious base (Kirisci \& Winrow 1997). Moreover, the empire did not interfere with the tribal structure and culture of the Kurdish people, so they stayed devoted to own traditions and system (Ozfidan \& Burlbaw \& Aydin 2018). Since its establishment in 1923, the Republic of Turkey has implemented a strategy in direction of creating an assumption that Turkey was settled by only one nation, which are Turks, and who spoke a sole language, which is Turkish (Polat 2007). So, Turkish became the only official language of the country. It was forbidden for the Kurdish people to use their mother tongue in public and at home, as well as schools and institutions (SkutnabbKangas \& Bucak 1994, as cited in Ozfidan \& Burlbaw \& Aydin 2018). Eventually, the law prohibiting the Kurdish language was passed in 1923 (May 2001; SkutnabbKangas \& Bucak 1994, as cited in Ozfidan \& Burlbaw \& Aydin 2018).

Kendal (1980) states that it was allowed to use the Kurdish language in daily life, however its usage was still banned in public in 1950. During the years between 1960 and 1990 both the Kurdish culture and language underwent many restraints (May 2001, in Ozfidan \& Burlbaw \& Aydin 2018). The Constitution of 1961 gave some freedoms regarding the organisation and mobilisation of the Kurds, for instance, it allowed the first journal in Kurdish to be published; however, the government still had a strict control over the Kurdish-populated areas (Çelik 2012). Currently the Kurds live in all geographical areas of Turkey, but are mainly concentrated in Eastern and South-eastern regions of the country. They mostly live in the mountainous areas, small cities and villages (Polat 2007). Additionally, agricultural cultivation and farming comprise the rural Kurdish economy (Ozfidan \& Burlbaw \& Aydin 2018). Even though Turkish education system is free and accessible to everyone at all levels, the literacy rate and school attendance in rural areas, particularly in Kurdish-populated regions, are much lower compared with the urban regions (Arslan 2005). The literacy rates are also the lowest in the Eastern and South-eastern regions of the country, which are predominantly Kurdish-populated areas (Ozfidan \& Ugurlu 2015). Moreover, illiteracy rates are higher among females than males (Polat 2007). In terms of the script, it can be said that the Kurds use three different alphabets. Kurds in Turkey and Syria use the Latin alphabet, Kurds in Iraq and Iran use the Arabic alphabet, and Kurds in the former Soviet Republics utilize the Cyrillic alphabet.

In relation to the language use, it is accepted to classify the language users in three different groups. So, the first group includes the people whose language is poor or who scarcely speak the language, but who believe that they are Kurdish ethnically (Smits \& Gündüz-Hoşgör 2003). The second group comprises the people who have never attended any state school in Turkish, they come from rural areas and speak solely the Kurdish language (Mutlu 1996). Mainly older men and women make up this group. Finally, the third group contains people who 
fluently know both languages - Turkish and Kurdish (Smits \& Gündüz-Hoşgör 2003). People who are native bilinguals and people who picked up the Turkish language once they started the school due to its necessity also placed in this group.

On January 1, 2009, the Turkish government allowed broadcasting in Kurdish. Broadcasting in Kurdish was also previously initiated in 2004, yet was not successful. Further, on 12 June 2012, the government of Turkey made a historical step and declared Kurdish to be an elective course and let it be taught in schools (Ozfidan \& Burlbaw \& Aydin 2018). This is also considered a step towards creating a bilingual education. However, lack of teachers, instruction materials, trainings are among the barriers towards implementing the teaching of this language at schools. These undertaken steps can also be regarded as turning points to some extent in resolving the existing conflict between two parties (Çelik 2012). It is also necessary to mention that in the last eighty years, the state of Turkey has moved forward from complete denial of Kurdish ethnicity to the recognition and acceptance of cultural differences and "a commitment to respect their culture" (Çelik 2012: 257). Among the challenges that need to be eliminated towards peaceful and harmonious coexistence are mutual mistrust, social polarisation between Kurds and Turks and non-recognition of the mistakes made in the past by both sides (Çelik 2012). In conclusion, it can be mentioned that because of negative policies applied towards Kurdish, and geographical and socio-economic reasons, there have been great challenges for the language, such as the lack of a common standard language, a unified writing system and mutual intelligibility across the main dialect groups. Kurdish language has been influenced by various aspects of the dominant state languages. Accordingly, sound system, vocabulary, grammar, idioms, and other discourse features of Kurdish language have been under strong impact of the dominant official languages (Sheyholislami 2015).

\section{The practice of naming children and its importance for people}

The process of choosing the names by parents for their children is quite intriguing. What worth attention is whether the parents make an individualistic choice or are impacted by such factors, as family relations, race, religion and ethnicity. There is a very limited literature on baby-naming, focused on the naming process and practices; on the other hand, books on baby-naming are exceptionally popular. The general tendency is to think that given names affect the baby's life, the way they think about themselves and how others think about them (Bryner 2010a).

It is also believed that names are influential in shaping children's behaviour and life outcomes (Edwards \& Caballero 2008). For instance, girly sounding names and unique baby names can cause hardships later in life (Bryner 2010a). Figlio (2005) suggests that girly sounding names given to boys, 
as Ashley and Shannon, and boy names given to girls, such as Madison, Taylor, are more likely to cause behavioural problems. He also states that girls having more feminine sounding names, as Anna, are more likely to prefer humanities to maths or science (Figlio 2005). In 2005, the Daily Mail announced the teachers' discussion over the behaviourally suggestive names, among which are the names of celebrities and the names from soap operas - Britney, Jordan, Chardonnay, Kyle (see Edwards \& Caballero 2008). A study conducted by Bounty.com (in Bryner 2010b) regarding usual and unusual names shows that parents who preferred unusual names for their babies are now regretting as they got fed up with explaining the meaning of the name and spelling it to others. Additionally, the study by Twenge \& Abebe \& Campbell (2010) suggests that parents who give unusual names to their children also have an unusual parenting style. At the same time parents nowadays choose rarer and unusual names for the babies (Bryner 2010b).

Studies examining the kinship relations were also conducted. It was found out that children names that link them to their fathers intensify the bonds between them (Furstenberg \& Talvitie 1980; Daly \& Wilson 1982). Additionally, some works suggest that boys named after paternal relations and girls for maternal kin truly strengthen the relations and even make them eternal, besides showing huge respect and affection (Edwards \& Caballero 2008). Undoubtedly, naming children after grandfathers or grandmothers, or even any other family bond is a widespread practice, mostly dictated by culture of the country. For instance, in Turkey, as in many countries of the East, it is also very common to name children after grandparents or other respected ancestors. Generally, grandparents are very influential in choosing a name for grandchildren. Moreover, it is very common to give two names to children; one as a first name, and another as a middle name. The choice of each name can be parted among parents and grandparents (Şaşmaz Kalaycioğlu 2018). Also, there is a commonplace tendency of giving religious names, which are Ali or Muhammed; or names that can be associated with courage or power-Aslan ('lion'), Korkmaz ('fearless'), Yiğit ('hero') (Şaşmaz Kalaycıoğlu 2018). Some families get inspired from natural events and pick up names like volcano, typhoon, which make up masculine names Volkan and Tufan respectively.

Statistics show that in 2019 a total of 1.180 .840 babies were born in Turkey, and $51 \%$ of new-borns were males and other $49 \%$ were females. The most popular female name chosen for babies was Zeynep, followed by Elif and Defne. For the boys the most favoured name, according to the list of TÜIK (Turkey's Agency for Statistics), was Yusuf, Eymen and Miraç. Names also display the cultural diversity elements of a particular society, for instance name Mohamed has been placed among the top twenty in 2004, and is getting more popular since then, which can be regarded as a reflection of modern British society (Womack 2006). Another important aspect of baby naming practice is children's own perceptions about their names. In this regard, Figlio (2005) 
states that a strong link between an individual's like or dislike of his or her name and high or low level of self-confidence exists. As children become older, they realise that their names possess the elements of their culture, minority, ethnic or religion affiliation that "singles them out from their peers" (Edwards \& Caballero 2008: 53). This, surely, depends on the residential area where they live, as people in culturally diverse and metropolitan areas are less likely to feel the differences. On the other hand, in small monocultural cities there is a higher probability of associating a name with particular ethnic, religious and other characteristics.

\section{Controversy over Kurdish naming in Turkish dominant society}

It was discussed above that parents might make an individualistic or an intentional choice in associating the name with family, ethnicity or faith when giving names to their children. Parents' desire in picking specific names, which will represent their cultural heritage, can be considered a completely natural process. However, the potential problem here is the following: names symbolising the ethnic, minority or religious affiliation can strengthen the risks of prejudice when encountering the wider society (Edwards \& Caballero 2008). This, surely, depends on the level of diversity of a particular country, region or area; and is not necessary happening everywhere. Minority-specific names, Kurdish names in this context, can cause some difficulties for people possessing them. This issue has a long prehistory, also deepening in politics, but what we are focusing on in this research are people's stories behind the political processes and all the fuss it caused for many years. However, mentioning some law regulations and their impact on human lives from Kurdish backgrounds is inevitable. In the last two decades, Kurdish families were facing hardships when trying to register Kurdish names of their children at the registration agencies (Aslan 2009). There are cases when the families did not register their children and waited till the government institutions allowed them to register children with Kurdish names (Aslan 2009).

To start with, in 1928 the "Law on the Acceptance and Application of Turkish Letters" was passed. Justification was made and this decision was approved by the relevant Law Department of the Supreme Court. The Ministry of Internal Affairs also informed all Population Directorates that Kurdish names containing the letters "X, W and Q" cannot be written in their identity cards with a circular issued after the approval of the Supreme Court. This is another reason for dissatisfaction of Kurds, when people cannot use distinctive names due to the reason that some letters do not exist in the official alphabet (Aslan 2009).

Unfortunately, we are not encountering this application for the first time. There are thousands of names that have no meaning in both languages, as they are written on the identity card. If these names are prepared with a dictionary called "Mutation-Given Kurdish Names Dictionary", I think that a tragicomic document has been created about the assimilation policies that Kurds have 
been struggling with for years. However, there are no obstacles in Kurdish names that can be written in Turkish letters (unless we count the letters with caps). In other words, you can give your child a name like $\breve{G} J C ̧ A P$ by bringing five randomly selected letters next to each other. Because the more meaningful these five letters are next to each other, the more meaningful is ŞEVVRA. In other words, as far as I understand, the civil servants do not look at the Turkish Language Institution's Great Turkish Dictionary and make no sense polls.

Further, in 1934 the Surname Law was passed by the Grand National Assembly. It aimed to carry modernization reforms regarding alphabet, language, music and etc. (Turkoz 2004). In addition, its primary goal was to grant legal rights and identify each individual as a legal person (Aslan 2009). Names owned by civil officers, tribes or foreign nations, unsuitable names were prohibited by the government (Turkoz 2004). Moreover, such affiliations as efendi, pasha, bey, religious and tribal titles that were used during the Ottoman Empire were also annulled (Turkoz 2004). Language Law, which was passed earlier in 1928 and replaced the words of Arabic and Persian origins with newly invented Turkish equivalents, was an important motive for the Surname Law in a way that the newly adapted surnames were Turkic surnames, as the ones affiliated with foreign nations or ethnicities were banned. It can be stated that the law broke up the existing tribal structures in some sense, and, most importantly intensified the sense of Turkishness within diverse society (Aslan 2009). During these years many Kurds, especially the ones living in urban areas, selected pure Turkish names and names that were important in Turkish history for their children (Kutlay 1997). The usage of Turkish names spread all over the country and population since the establishment of the Republic, however, it was regarded as a very slow process in the beginning (Bulliet 1978). At the same time, it can be estimated that the duration of this process in urban and rural areas was completely different; yet people in rural areas often were given names by officials. Executives were making changes in original names by cutting off an ending which stamped the name as ethnic, modifying the name and making it sound as a pure Turkish one or simply translating the name from minority language to Turkish (Turkoz 2007). It can be estimated that doing so even deepened the issue and created the way more problems for the people carrying Kurdish specific names. Their stories are the topic of the next chapters.

\section{Methodology}

The study has a qualitative research strategy, which was purposefully chosen due to the reason that it allows the researcher to make an in-depth analysis, explore and understand the complexity of a phenomenon (Williams 2007). Further, the details of the study were developed and there is a strong correlation between the researcher and the collected data. This research mainly 
focuses on the issue of Kurdish naming in Turkish dominant society, hence two research aspects/questions can be identified, which are as follows:

1) Kurdish names that got meaningless once written in Turkish;

2) Problems that Kurdish people faced after the Alphabet Regulation ("Law on the Acceptance and Application of Turkish Letters", 1928) changed their names.

There is an extremely limited literature on the issue, thus our research can be regarded as a purely explanatory one. Moreover, there is no existing theory that can be tested, so we firstly collected the data, then we will compare and contrast it, and finally, discuss and analyse in order to come up with potential new findings.

Snowball qualitative or chain method was used to find the participants. This method is an efficient and cost-effective to access people who would otherwise be very difficult to find. In this method, the researcher asks the first few samples, who are usually selected via convenience sampling, if they know anyone with similar views or situations to take part in the research (Naderifar \& Goli \& Ghaljaei 2017). The involved seven participants from Kurdish background, who at least once or several times during their lifetime have experienced a difficulty or undergone a problem because of having Kurdish specific name. In order to collect the data and examine difficult questions, we held seven unstructured interviews with participants. One of the limitations of this study might be small sample size because generally the individuals having name problem in question are not volunteer to participate because of political or private reasons. The duration of the interviews is different; some lasted for ten minutes, while in cases where respondents were inclined to talk more about their stories interviews even lasted for twenty-five minutes. The interviews were recorded and then transcribed. The characteristics of the interviewees are presented separately below (Table 1).

Table 1: Characteristics of the respondents

\begin{tabular}{|l|l|l|l|l|l|}
\hline No. & Name & Age & Gender & Marital Status & Occupation \\
\hline 1. & Kewi & 44 & Female & Married & Housewife \\
\hline 2. & Verdek & 43 & Female & Married & Housewife \\
\hline 3. & Bişeng & 22 & Female & Single & Student \\
\hline 4. & Zînar & 33 & Male & Married & Teacher \\
\hline 5. & Xende & 44 & Female & Married & Housewife \\
\hline 6. & Mizgîn & 24 & Female & Single & Student \\
\hline 7. & Qazê & 54 & Female & Married & Female \\
\hline
\end{tabular}

\section{Findings and discussion}

The research findings suggest that all seven participants felt embarrassed because their names got meaningless or got awkward meanings once pronounced or written in Turkish. This happened mainly because some letters in the Kurdish language do not exist in Turkish. When these people got registered at the registry office, the "problematic" letters of Kurdish got replaced with the Turkish ones, 
which eventually destroyed the whole meaning of the names.

Continuing with this idea and giving examples, it can be stated that our interviewee Kewi's name was changed to Keklik, which means 'partridge' in English, and Verdek's name to Ördek ('duck'), Xende's to Hindi ('turkey'), Bîşeng's name to Bişek, which does not have any meaning in Turkish as in many other cases. It is not difficult to imagine what these people went through or felt every time there was a need to spell or pronounce their names. This factor was significantly influential during interviewees' school years. For some of them, it continued even during high school and university years. For instance, four out of seven participants stated that they did not want to continue education because of problematic names and skipped the first classes at school. To check the attendance, the class teacher had to spell out the name. Additionally, our participants mentioned that because of their names, they experienced child bullying at a very early age at school, which indeed broke their confidence. Eventually, their schooling years finished four-five years after it had started.

Verdek highlighted that it was challenging to live with this name and shared a story from her school years: "It was tough to build relations with my classmates because every time they heard my name, they were imitating the duck sounds... We had a very nice and understanding teacher, who talked to me once and proposed to give me her mother's name. I immediately agreed and felt so much revealed!"

As it can be understood from Verdek's example, the names built up barriers that were hard to navigate at young ages, and they affected personal and social aspects of participants lives. Supporting this argument, Zînar continued:

Due to the fact that the letter " 1 " was prohibited, the officer at the registry office wrote my name down as "Zinar". In Kurdish, my name means 'a rock', 'healthy', but if you simply translate it to Turkish it would mean... sorry... but it means 'to commit adultery'. Living in a very conservative society and possessing a name like this... you cannot imagine how difficult it could only be. At high school, there was a girl I loved, but she refused me when I asked her out... "Change your name", she said.

Two of the participants pointed out that they would love to change their names but have not done it before for various reasons - one did not know how to proceed with the procedure, and the other did not want to talk about it to her family. The other two interviewees eventually changed their names, for instance, Zînar changed his name to Musa, and Xende changed her name to Hande first, but after moving to Istanbul, she started to use the name Ayşe. One of the participants took a name that the teacher proposed, yet the other two did not want to change their names.

In this regard, Bîşeng stated: "One day if the Kurdish alphabet would be allowed, I would register my name as it is, with the letter ' $\hat{1}$ ', because it is a part of my mother tongue and culture, hence very important for me". 
Mizgîn remarked that her name in Kurdish means 'good news', but once written in Turkish as Mizgin, then in Kurdish it means 'the one who pees' enough reason to get embarrassed when your name is spoken up, she mentioned. In addition, she states that "being born as a Kurd or having a Kurdish name did not have to make me experience this all". Even though Kurdish specific names create several troubles and are very harsh in some cases, some people do not want to give up on their cultural and ethnic features and change their names, which is entirely natural. In this regard, we cannot deny that some names in Kurdish nicely reflect the elements of culture and ethnicity, however once translated to Turkish, they mean the opposite.

The case of Qazê is proof of this, whose name is written as Kaze in her identity card. When translated from Kurdish, it means 'a swan' and 'a goose' when translated from Turkish, while their places in the two cultures are entirely different. She continues: "There is a metaphor existing in our culture regarding a woman's beauty and walking, as it is often compared to the swan's beauty. A lot of songs about swans exist in our culture and you can complement a woman by so, however if in Turkish you say to a woman that she looks like a goose or she is like a goose, she will obviously get offended. This is a difference".

Because of all the difficulties our interviewees had to face during their lives and the total negative impact on them, they do not want their children to experience the same problems. Four out of seven people we interviewed stated that they were very decisive in not picking up specific Kurdish names for their children. They intentionally chose general Turkish names or the ones that would sound equally good in Turkish and Kurdish.

In conclusion, it can be stated that Kurdish specific names create many problems for people from this background; they impact severely, in some cases even destroy their school, social and personal lives. Many of them felt hesitant to participate in any social activities as they could not bear their names to be loudly pronounced when there is an audience. Approximately all of the participants did not attend the first classes at the school, which ended up not concentrating on the academic and social sides of the school. Moreover, names broke their self-confidence and ruined their encouragement for further studies. The last sentence for this chapter can be the words of one of our interviewees, who stated that you could not be successful where you are not happy. Lastly, considering that many Kurdish names got meaningless or got an odd sense when translated to Turkish, some can be seen below, in Table 2. The data in the table show that the Kurdish names have decent meanings in Kurdish culture; however, when they are written in Turkish alphabet, they either lose their meanings and become totally meaningless or they have unappreciated meanings in Turkish. Choosing between a relatively cute, casual name and a really uncanny one can definitely make an impact on individuals bearing this name (Twenge \& Manis 1998). 
Table 2: Some Kurdish names in Kurdish-Turkish and their meanings accordingly

\begin{tabular}{|c|c|c|c|c|}
\hline $\begin{array}{l}\text { Kurdish } \\
\text { orthography }\end{array}$ & Gender & $\begin{array}{l}\text { Kurdish } \\
\text { Meaning }\end{array}$ & $\begin{array}{l}\text { Turkish } \\
\text { orthography }\end{array}$ & $\begin{array}{l}\text { Turkish } \\
\text { meaning }\end{array}$ \\
\hline Axîn & Female & 'sigh' & Ahin & No meaning \\
\hline Berzê & Female & $\begin{array}{l}\text { 'honourable } \\
\text { woman' }\end{array}$ & Berze & No meaning \\
\hline Daxaz & Female & 'desire' & Dahaz & No meaning \\
\hline Dîlxwaz & Female & 'wholehearted' & Dilhaz & Taste of tongue \\
\hline Evîn & Female & 'love' & Evin & Your house \\
\hline Gewrê & Female & 'pretty woman' & Gevri & No meaning \\
\hline Hîvbanban $\hat{u}$ & Female & $\begin{array}{l}\text { 'the princess of } \\
\text { moon' }\end{array}$ & Hivbanu & No meaning \\
\hline Kulîlq & Female & 'the wild flower' & Kulilk & No meaning \\
\hline Awlr & Male & 'view' & Avir & No meaning \\
\hline Dilxweş & Male & 'delighted' & Dilheş & No meaning \\
\hline Hewar & Male & 'outcry' & Hevar & No meaning \\
\hline Mérxas & Male & 'valiant' & Merhas & No meaning \\
\hline Jêhat & Male & 'hardworking' & Jihat & No meaning \\
\hline Bawer & Male & 'believer' & Baver & No meaning \\
\hline Cîgerxwîn & Male & $\begin{array}{l}\text { 'bleeding liver } \\
\text { (brave)' }\end{array}$ & Ciyerhun & No meaning \\
\hline Welat & Male & 'homeland' & Velat & No meaning \\
\hline
\end{tabular}

\section{Conclusion}

Hakuta (2009) states that various circumstances that cause language contact can be a reason for bilingualism. Bilingualism in the officially bilingual countries, such as Canada and Belgium, and bilingualism caused by growing up in an immigrant community in New York are different from each other (Hakuta 2009). Moreover, there are also officially multilingual countries - South Africa, Switzerland, Luxembourg, Singapore, where the geographical region defines the dominance of one particular language. In this context, it is necessary to mention that bilingualism on social and individual levels are different concepts, and bilingualism does not necessarily guarantee bilingualism on a personal level (Wei 2006). That is to say, even though the countries mentioned above are relatively bilingual or multilingual, it does not mean that all the residents of the country know and can utilise two, three or more official languages of the country at equally good levels. In this regard, Mackey (1962) suggests that the primary goal of the state is the maintenance and use of languages in the same nation, not the promotion of bi- or multilingualism among its citizens.

According to the U.N.'s declarations, providing an education in the language of a minority group should also be a primary goal of the states. However, even in this case, we have the conditions that seriously care about it and others that somehow neglect the seriousness of the issue. We can culminate 
from the article that there are plenty of positive examples regarding minority societies and educational opportunities; among these countries are Canada, the United States of America partly, the Basque region of Spain, Wales in the United Kingdom, etc. In Turkey, despite being a diverse and multicultural country, the representatives of Kurdish minority society continue to experience challenges in their social and personal lives. As stated above, the fundamental legal framework for the minority groups in Turkey is the Treaty of Lausanne signed in 1923. However, it created a puzzle between the legal framework and the existing situation because there is a gap between the legal rights and their relevance to minority regime in Turkey (Toktas \& Aras 2009).

The principle of respecting the culture of ethnicities is taken more seriously in recent years, and there are some turning points in eliminating the mistrust between two parties. One of them is allowing the broadcasting in Kurdish in 2009, and the other one is starting from 2012, making Kurdish an elective course at schools. This study also focused on the difficulties of having Kurdish specific names in Turkey, and in this regard, some conclusions can be made. Due to the legal acts, as the Law on the Acceptance and Application of Turkish Letters (1928) and the Surname Law (1934), many people from the Kurdish background had to pick up names in Turkish, and their names and surnames were altered. Moreover, the former act prohibited the usage of some Kurdish specific letters, and this is precisely the reason why so many problems occurred. Consequently, sad human stories evolved from the problem. Additionally, people had to go through many hardships, and therefore they negatively influenced nearly all aspects of their lives. People's names got odd meanings or became meaningless at all, and the outcomes of this practice were tragic for many of them, which is given in the Findings and Discussion section in a more detailed way.

\section{References}

Andrews, P.A. 1992. Türkiye'de Etnik Gruplar [Ethnic groups in Turkey]. İstanbul: Ant Yayınları.

Arslan, Can. 2005. Reform in education. Ankara: Ankara University, Institute of Educational Sciences Publications.

Aslan, Senem. 2009. Incoherent state: The controversy over Kurdish naming in Turkey. European Journal of Turkish Studies 10. DOI: https://doi.org/ $10.4000 /$ ejts. 4142

Bryner, Jeanna. 2010a. Good or bad, baby names have long-lasting effects. Livescience. (https://www.livescience.com/6569-good-bad-baby-nameslong-lasting-effects.html) (Accessed 2020-07-16.)

Bryner, Jeanna. 2010b. Parents choosing more unusual baby names now. Livescience. (https://www.livescience.com/9841-parents-choosing-unusualbaby-names.html) (Accessed 2020-07-16.)

Bulliet, R. W. 1978. First names and political change in modern Turkey. 
International Journal of Middle East Studies 9(4), 489-495.

Çelik, A.B. 2012. Ethnopolitical conflict in Turkey: From the denial of Kurds to peaceful co-existence? In Landis, D. \& Albert, R. (eds), Handbook of ethnocultural conflict, 241-260. Boston, MA: Springer.

Daly, Martin \& Wilson, Margo I. 1982. Whom are new-born babies said to resemble? Ethology and Sociobiology 3(2), 69-78. DOI: https://doi.org/ 10.1016/0162-3095(82)90002-4

Drange, L. D. 2011. The challenge of bilingualism in a multilingual society: The Bolivian case. Journal of Intercultural Communication 27. (https:/immi.se/ intercultural/nr27/drange-27.htm) (Accessed 2020-07-15.)

Edwards, John. 2005. Foundations of bilingualism. In Bhatia, Tej K. \& Ritchie, William C., The handbook of bilingualism, 7-31. Malden, MA: Blackwell.

Edwards, Rosalind \& Caballero, Chaion. 2008. What's in a name? An exploration of the significance of personal naming of 'mixed' children for parents from different racial, ethnic and faith backgrounds. The Sociological Review 56(1), 39-60. DOI: https://doi.org/10.1111/j.1467-954X.2008.00776.x

European Charter for Regional or Minority Languages. 1992. Nationalities Papers 27(1), 139-154. DOI: 10.1080/009059999109235

Fielding, Ruth. 2015. Multilingualism in the Australian suburbs: A framework for exploring bilingual identity. Singapore: Springer.

Figlio, David. 2005. Names, expectations and the Black-White test score gap. Cambridge, Mass.: National Bureau of Economic Research.

Furstenberg, Frank F., Jr., \& Talvitie, Kathy Gordon. 1980. Children's names and paternal claims. Journal of Family Issues 1(1), 31-57. DOI: https://doi.org/ 10.1177/0192513X8000100103

Gorter, Durk. 2013. Multilingual interaction and minority languages: Proficiency and language practices in education and society. Language Teaching 48(1), 82-98. DOI: https://doi.org/10.1017/S0261444812000481

Gunter, M. M. 1997. The Kurds and the future of Turkey. New York: St. Martin's Press.

Hakuta, Kenji. 2009. Bilingualism. In Squire, L. R. (ed.), Encyclopedia of neuroscience, 173-178. London: Elsevier.

Izady, M. R. 1992. Kurds: A concise handbook. London: Taylor \& Francis.

Karimova, N. \& Deverell, E. 2001. Minorities in Turkey. Stockholm: The Swedish Institute of International Affairs.

Kaya, N. 2015. Teaching in and studying minority languages in turkey: a brief overview of current issues and minority schools. European Yearbook of Minority Issues Online 12(1), 315-338.

Kendal, N. 1980. The Kurds under the Ottoman Empire. In Chailand, G. (ed.), People without a country: The Kurds and Kurdistan, 47-106. London: Zed Books Ltd.

Kirisci, K. \& Winrow, G. M. 1997. The Kurdish question and Turkey: An example of a trans-state ethnic conflict. Portland, Oregon: Frank Cass Publishers. 
Kutlay, N. 1997. Kürt Kimliği Oluşum Süreci [The formation of Kurdish identity]. Istanbul: Belge Yayınları.

Lavoie, C. 2011. The educational realities of Hmong communities in Vietnam: The voices of teachers. Critical Inquiry in Language Studies 8(2), 153175. DOI: https://doi.org/10.1080/15427587.2011.571348

Mackey, W. 1962. The description of bilingualism. Canadian Journal of Linguistics/Revue canadienne de linguistique 7(2), 51-85. https://doi.org/ $10.1017 / \mathrm{S} 0008413100019393$

May, S. 2001. Language and minority rights: Ethnicity, nationalism, and the politics of language. New York: Longman.

McDowall, D. 1997. A modern History of the Kurds. London: I.B. Tauris.

Mutlu, S. 1996. Ethnic Kurds in Turkey: A demographic study. International Journal of Middle East Studies 28(4), 517-541. DOI: https://doi.org/ $10.1017 / /$ S0020743800063819

Myers-Scotton, C. 2007. Multiple voices: An introduction to bilingualism. Carlton: Blackwell.

Naderifar, Mahin \& Goli, Hamideh \& Ghaljaei, Fereshteh. 2017. Snowball sampling: A purposeful method of sampling in qualitative research. Strides in Development of Medical Education 14(3), 1-4. DOI: 10.5812/sdme.67670

Nguyen, Trang. 2018. Bilingual identity of ethnic minority students: insights from Vietnam. International Journal of Bilingual Education and Bilingualism 24(1), 1-16. DOI: 10.1080/13670050.2018.1445697

Nguyen, Trang \& Hamid, M. 2016. Language attitudes, identity and L1 maintenance: A qualitative study of Vietnamese ethnic minority students. System 61, 87-97. DOI: https://doi.org/10.1016/j.system.2016.08.003

Nguyen, Trang \& Hamid, M. 2017. Bilingualism as a resource: Language attitudes of Vietnamese ethnic minority students. Current Issues in Language Planning 19(4), 343-362. DOI: https://doi.org/10.1080/ 14664208.2017.1337922

Ozfidan, Burhan \& Burlbaw, L. \& Aydin, H. 2018. The minority languages dilemmas in Turkey: A critical approach to an emerging literature. Journal of Educational Issues 4(1), 1-19. DOI: https://doi.org/10.5296/ jei.v4i1.11498

Ozfidan, Burhan \& Ugurlu, Omer. 2015. The idea of race and racial differences. Electronic International Journal of Education, Arts, and Science 1(1), 85-98.

Poissant, Helene. 2005. Bilingualism, bilingual education, and sociocultural identity: The experience of Quebec. Journal of Cognitive Education and Psychology 4(3), 316-328. DOI: 10.1891/194589505787382658

Polat, Nihat. 2007. Socio-psychological factors in the attainment of L2 native-like accent of Kurdish origin young people learning Turkish in Turkey. (https:// www.researchgate.net/publication/37256422) (Accessed 2020-07-16.)

Romaine, Suzanne. 1995. Bilingualism. Studies in Second Language Acquisition 18(3), 369-379. DOI: https://doi.org/10.1017/S0272263100015096 
Romaine, Suzanne. 2006. Language policy in multilingual educational contexts. In Brown, Keith (ed.), Encyclopedia of language and linguistics, 2nd ed., 584-596. Oxford: Elsevier.

Şaşmaz Kalaycioğlu, S. 2018. What's in a name? On naming children in Turkey. (https://yabangee.com/whats-in-a-name-on-naming-children-in-turkey/) (Accessed 2020-07-15.)

Sheyholislami, Jaffer. 2011. Kurdish identity, discourse, and new media. New York: Palgrave Macmillan.

Skutnabb-Kangas, T. 1981. Bilingualism or not: The education of minorities. Clevedon: Multilingual Matters.

Smits, J. \& Gündüz-Hoşgör, A. 2003. Linguistic capital: Language as a socioeconomic resource among Kurdish and Arabic women in Turkey. Ethnic and Racial Studies 26(5), 829-853. DOI: https://doi.org/10.1080/ 0141987032000109050

Spolsky, Bernard. 2004. Language policy. Cambridge: Cambridge University Press.

Tabouret-Keller, A. 1998. Language and identity. In Coulmas, Florian (ed.), The handbook of sociolinguistics, 315-326. Oxford: Blackwell.

Toktas, Sule \& Aras, Bulent. 2009. The E.U. and Minority Rights in Turkey. Political Science Quarterly 124(4), 697-720. DOI: https://doi.org/ 10.1002/j.1538-165X.2009.tb00664.x

Turkoz, Meltem. 2004. The social life of the state's fantasy: Memories and documents on Turkey's 1934 Surname Law. University of Pennsylvania. (Unpublished $\mathrm{PhD}$ dissertation.)

Turkoz, Meltem. 2007. Surname narratives and the state-society boundary: Memories of Turkey's Family Name Law of 1934. Middle Eastern Studies 43(6), 893-908.

Twenge, J. M. \& Abebe, E. M. \& Campbell, W. K. 2010. Fitting in or standing out: Trends in American parents' choices for children's names, 1880-2007. Social Psychological and Personality Science 1, 19-25. https://doi.org/ 10.1177/1948550609349515

Twenge, J. M. \& Manis, M. 1998. First name desirability and adjustment: Selfsatisfaction, others' ratings, and family background. Journal of Applied Social Psychology, 28, 41-51.

Wei, L. 2006. Bilingualism. In Brown, Keith (ed.), Encyclopedia of language and linguistics, 2nd ed., 1-12. Oxford: Elsevier.

Williams, Carrie. 2007. Research methods. Journal of Business \& Economic Research 5(3), 65-72. DOI: https://doi.org/10.19030/jber.v5i3.2532

Womack, Sarah. 2006. Mohammed overtakes George in list of most popular names. The Telegraph, 21 December. (https://www.telegraph.co.uk/ news/uknews/1537504/Mohammed-overtakes-George-in-list-of-mostpopular-names.html) (Accessed 2020-07-16.) 